\title{
Normal pituitary hormone response to thyrotrophin and gonadotrophin releasing hormones in subjects exposed to elemental mercury vapour
}

\author{
Eva Marie Erfurth, Andrejs Schütz, Anita Nilsson, Lars Barregård, Staffan Skerfving
}

\begin{abstract}
Exposure to elemental mercury (Hg) vapour results in an accumulation of $\mathrm{Hg}$ in the pituitary, the thyroid, and the testis. In this study, basal serum concentrations of pituitary hormones (thyrotrophin (TSH), prolactin (PRL), follicle stimulating hormone (FSH), and luteinising hormone (LH)) or their response after administration of thyrotrophin and gonadotrophin releasing hormones did not differ between 11 male workers (mean urinary Hg (U Hg) concentration $26 \mathrm{nmol} / \mathrm{mmol}$ creatinine) and nine male dentists (U Hg concentration $1.3 \mathrm{nmol} / \mathrm{mmol}$ creatinine) exposed to elemental $\mathrm{Hg}$ vapour when compared with matched referent groups ( $U$ Hg concentration 0.6 and $0.4 \mathrm{nmol} / \mathrm{mmol}$ creatinine). Thus there was no evidence of an effect of $\mathrm{Hg}$ on the pituitary. Neither was there any association between exposure to $\mathrm{Hg}$ and serum concentrations of free thyroid hormones (S FT $3, S_{3}$ FT $_{4}$ ), testosterone, or cortisol. Increased plasma concentrations of selenium (Se) were associated with increased basal serum concentrations of TSH, decreased concentrations of basal serum cortisol, and decreased release of FSH.
\end{abstract}

Samples taken at necropsy from industrial workers exposed to elemental mercury $(\mathrm{Hg})$ vapour $^{12}$ and dentists ${ }^{3}$ showed high concentrations of $\mathrm{Hg}$ in the pituitary gland. Accumulation of $\mathrm{Hg}$ at this site also occurred in experimental animals after exposure to inorganic $\mathrm{Hg}^{.}{ }^{4}$ It is not known, however, whether mercury affects pituitary function. The thyroid

\footnotetext{
University Hospital, S-221 85 Lund, Sweden

Department of Internal Medicine

E M Erfurth

Department of Occupational Medicine

A Schütz, A Nilsson, S Skerfving

Department of Occupational Medicine, Sahlgren Hospital, University of Gothenburg, St Sigfridsgatan 85, S-412 66 Gothenburg, Sweden L Barregård
}

gland also accumulates $\mathrm{Hg}$ as was first shown decades ago $^{5}$ and confirmed more recently. ${ }^{1}$ The functional consequences of this have been studied in pigs and rats $^{67}$ but not in humans. The testis accumulates $\mathrm{Hg}^{5}$ but it is not known if this affects testosterone secretion.

Selenium (Se) influences some hormonal functions ${ }^{89}$ and modifies the metabolism and toxicity of both inorganic $\mathrm{Hg}$ salts and methyl- $\mathrm{Hg}$ in experimental animals. ${ }^{10}$ Further, there is probably an interaction between $\mathrm{Hg}$ and $\mathrm{Se}$ in man, as indicated by studies of concentrations of the elements in blood and urine ${ }^{1112}$ and in organs, including the pituitary and thyroid glands, from necropsies carried out on workers exposed to elemental $\mathrm{Hg}$ vapour. ${ }^{1}$

To investigate if exposure to elemental $\mathrm{Hg}$ vapour had a negative effect on the secretion of pituitary hormones and on thyroid and testicular function, industry workers and dentists exposed to $\mathrm{Hg}$ vapour were compared with age matched unexposed controls with respect to thyrotrophin releasing hormone (TRH) and gonadotrophin releasing hormone (GnRH) stimulation tests. Furthermore, possible associations between hormones and $\mathrm{Se}$ state were investigated.

\section{Material and methods SUBJECTS}

The group of workers comprised seven male workers from a chloralkali plant, three repairmen from a fluorescent tube factory, and one worker from a $\mathrm{Hg}$ refinery. The mean exposure time was 4.5 (range 218) years. During the exposure period, blood $\mathrm{Hg}$ (B Hg) was determined more or less regularly in all except the refinery worker. The individual average $B$ $\mathrm{Hg}$ calculated from all observations on each subject varied between 70 and $170 \mathrm{nmol} / \mathrm{l}$. No time trends in the individual concentrations were found. For the refinery worker, who had the greatest intensity and duration of exposure, an average $\mathrm{B} \mathrm{Hg}$ concentration of $275 \mathrm{nmol} / 1$ could be calculated only for the last eight of the total of 18 years exposure. From a few measurements made during the first 10 years, an average twice as high might be assumed during that period. For the seven chloralkali workers and the refinery worker, data on previous urinary $\mathrm{Hg}(\mathrm{U} \mathrm{Hg})$ 
concentrations were available. Among the chloralkali workers $90 \%$ of the $\mathrm{U} \mathrm{Hg}$ values in the morning spot samples were within $25-50 \mathrm{nmol} / \mathrm{mmol}$ creatinine. For the refinery worker, the average of 117 (range 34-195) $\mathrm{nmol} / \mathrm{mmol}$ creatinine (seven samples), was for the past 18 months only. The mean age of the group was 33 (range 23-49). Their referent group (referents I) consisted of 10 age matched (mean 32, range 24-39 years) male municipal workers who had had no occupational exposure to $\mathrm{Hg}$.

The group of dentists comprised nine men who had been practising for an average of 28 (range 25-30) years, and who were still working as dentists. In this group, no information was available concerning earlier $\mathrm{B} \mathrm{Hg}$ or $\mathrm{U} \mathrm{Hg}$ concentrations. The mean age of the dentist group was 57 (range 55-62). Their referent group (referents II) consisted of 11 age matched (mean age 57, range 51-62) male municipal workers.

The subjects were studied after giving informed consent, and the study was approved by the Ethical Committee of Lund University, Sweden.

\section{STUDY PROTOCOL}

The investigations were performed from a Tuesday through Saturday. From history and physical examination, all subjects were considered healthy and had blood pressure and liver and kidney function within reference limits. Body mass index did not differ between groups. None of the subjects was taking medication, and none had been heavily exposed to alcoholic beverages or to organic solvents.

Amalgam fillings (I Akesson et al, personal communication) and fish consumption ${ }^{13}$ were registered. The dentists' referent group had a significantly lower number of amalgam fillings, which was due to an increased number of dental prostheses. The mean weekly fish consumption did not differ between the groups.

For the hormone studies, all subjects were investigated in a supine position between 8.00 and 10.00 am after an overnight fast. After resting in a supine position for 15 minutes, $100 \mu \mathrm{g} \mathrm{GnRH}$ and $200 \mu \mathrm{g}$ TRH were injected consecutively ( 0 minutes) through an indwelling needle in an antecubital vein. No difference in the pituitary hormone responses was found if $\mathrm{GnRH}$ and TRH were given alone or in combination..$^{14}$ Blood samples for measurement of serum thyrotrophin (S TSH), follicle stimulating hormone (S FSH), luteinising hormone (S LH), and prolactin (S PRL) concentrations were collected at $-15,0,10,20,30,45$, and 60 minutes. Blood samples for determination of serum cortisol ( $\mathrm{S}$ cortisol) concentrations were collected at -15 and 0 minutes. At 0 minutes the serum samples were collected for measurement of free thyroxine $\left(\mathrm{S} \mathrm{FT}_{4}\right)$, free triiodothyronine $\left(\mathrm{S} \mathrm{FT}_{3}\right)$, sex hormone binding glubulin (S SHBG), free testosterone ( $\mathrm{S} f$ test), total testosterone (S t test), bilirubin, alkaline phosphatase, $\lambda$-glutamyl transpeptidase, aspartate and alanine aminotransferases, creatine, and albumin concentrations or activities. Blood and plasma were collected for determination of $\mathrm{Hg}$ (erythrocyte (Ery) $\mathrm{Hg}$ and plasma (PHg)) and $\mathrm{Se}(\mathrm{P} \mathrm{Se})$ concentrations.

For all pituitary hormones and cortisol, the basal hormone concentrations were calculated from the mean of the concentrations in samples collected at -15 minutes, and 0 minutes. To summarise responses at different times and adjust for basal concentration differences, incremental areas were used to measure the responses of $\mathrm{LH}$ and FSH to $\mathrm{GnRH}$, and TSH and responses of PRL to TRH. To measure the relative increment of serum TSH, PRL, $\mathrm{LH}$, and FSH after TRH and GnRH stimulation, the ratios of incremental areas and the basal hormone concentrations were measured (IA/basal hormone concentration). The $\mathbf{S} \mathbf{f}$ test concentration was calculated by a direct method (radioimmunoassay) and from the ratio of $S t$ test and SHBG ( $S t$ test/ S SHBG). ${ }^{15}$

Ten dentists entered the study but one was excluded because of low total and free testosterone concentrations together with high S LH and S FSH concentrations because of a history of orchitis.

Urine was collected during an eight hour perioof the night before the investigation and $\mathrm{U} H g$ albumin, and creatinine concentrations were deter mined.

\section{HORMONE ASSAYS}

Serum samples were stored at $-20^{\circ} \mathrm{C}$. For each hormone, all samples from each subject were analysed in the same assay. In each assay, samples from exposed subjects and their referents were mixed in equal proportions and assayed in duplicate, except for $\mathrm{S} f$ test, which was assayed in triplicate.

Serum FSH, SLH and S cortisol concentrations were measured by specific double antibody assays (radioimmunoassays; Farmos Diagnostica, Turku, Finland). The intra and interassay coefficients of variation (CVs) for S FSH and S LH were $\leq 5.5 \%$. The reference range was 0.8-22 IU/1 for S FSH and 2-15 IU/1 for S LH. For S cortisol, the intra and interassay CVs were $\leq 5 \%$. Serum TSH and S PRL were analysed with a fluoroimmunoassay technique (Delfia, LKB, Finland). For S TSH and S PRL, the intra-assay CVs were $5 \%$ and $6.9 \%$, and the interassay CVs were $2.6 \%$ and $6 \%$. The reference interval for S TSH was 0.3-3.8 IU/1 and for S PRL $2-12 \mu \mathrm{g} / 1$.

Serum $\mathrm{FT}_{3}$ and $\mathrm{S} \mathrm{FT}_{4}$ were assayed by radioimmunoassay (Amersham International, Amersham, UK), with intra-assay CVs of $2.9 \%$ and $4.7 \%$ and interassay CVs of $3.7 \%$ and $6.9 \%$. The reference interval for $\mathrm{S} \mathrm{FT}_{3}$ was $2.9-8.9 \mathrm{pmol} / 1$ and for $\mathrm{S} \mathrm{FT}_{4}$ 10-25 pmol/1. Serum SHBG concentration was 
Normal pituitary hormone response to thyrotrophin and gonadotrophin releasing hormones in subjects exposed to elemental mercury vapour

measured by radioimmunoassay ${ }^{16}$ with intra and interassay CVs of $4 \cdot 1 \%$ and $7 \cdot 2 \%$. The reference interval was $0.5-4 \mathrm{mg} / \mathrm{l}$. Serum $\mathrm{f}$ test was measured by radioimmunoassay (DPC, LA, USA), with an intra-assay CV of $11 \%$. For normal adult men the reference range was 31-163 pmol/1. Serum t test was measured by radioimmunoassay with an intra-assay $\mathrm{CV}$ of $4 \%$.

\section{METAL ANALYSIS}

Mercury concentrations in urine, plasma, and erythrocytes were determined by a cold vapour atomic absorption technique. ${ }^{17} 18$ The detection limit was $1.0 \mathrm{nmol} / 1$ in urine and plasma and $2.0 \mathrm{nmol} / 1$ in erythrocytes. Each sample was analysed in duplicate. The precision, as calculated from duplicate analyses and expressed as CVs, was for $\mathrm{U} \mathrm{Hg} 12 \%, 5 \%$ and $2 \%$ in the concentration ranges $1-10$ (mean $=4 \cdot 8$, $\mathrm{n}=21), 10-50$ (mean $=19, \mathrm{n}=11$ ), and $50-750$ (mean $=393, \mathrm{n}=11$ ) $\mathrm{nmol} / \mathrm{l}$. For $\mathrm{P} \mathrm{Hg}$, the CVs were $11 \%, 3 \%$, and $1 \%$ in the concentration ranges 1-10 (mean $=4.4, n=27$ ), $10-50$ (mean $=23$; $\mathrm{n}=8$ ), and 50-175 (mean $=114, \mathrm{n}=8) \mathrm{nmol} / \mathrm{l}$. For Ery $\mathrm{Hg}$ the CVs were $7 \%, 3 \%$, and $2 \%$ in the concentration ranges 6-25 (mean $=18, \mathrm{n}=22$ ), 2650 (mean $=36, \mathrm{n}=10$ ) and 51-310 (mean 113; $\mathrm{n}=11) \mathrm{nmol} / \mathrm{l}$. The accuracy was checked by analyses of a reference sample (Seronorm, Nycomed, Oslo, Norway) with a value of $5.6 \mathrm{nmol} / 1$. Our results from different runs averaged $6.5 \mathrm{nmol} / 1$ (SD 0.87 range $5 \cdot 6-8 \cdot 0, n=6$ ). For a lysphilised urine sample (Lanonorm, Nycomed, Oslo) with a reference value of $49 \mathrm{nmol} / \mathrm{l}$ our average result was $49 \mathrm{nmol} / \mathrm{l}$
(SD 4.0, range 45-60, $\mathrm{n}=12$ ). Plasma Se concentration was determined by a fluorimetric method. ${ }^{19} 20$ The detection limit was about $0.03 \mu \mathrm{mol} / \mathrm{l}$. The CV calculated from duplicate analyses was $4 \%$. The accuracy was checked by analyses of a reference sample (Seronorm TM, Nycomed, Oslo) containing $1.14(\mathrm{SD} 0.08) \mu \mathrm{mol} / \mathrm{l}$. The result obtained was 1.13 (SD 0.05) $\mu \mathrm{mol} / 1(\mathrm{n}=10)$.

\section{OTHER ANALYSES}

Serum samples were analysed for concentration or activity of bilirubin, alkaline phosphatase, $\lambda$ glutamyl transpeptidase, aspartate and alanine aminotransferases, creatinine, and albumin, and urine samples were analysed for albumin by routine methods. Urinary creatinine was analysed according to Lustgarten \& Wenk. ${ }^{21}$ (and P Mascon, personal communication). The precision was $5 \%$ in the concentration range of 5-39 mmol/1. Urinary $\mathbf{~} \mathrm{gg}$ concentrations were corrected for creatinine concentrations and expressed as $\mathrm{nmol} \mathrm{Hg} / \mathrm{mmol}$ creatinine.

\section{STATISTICAL METHODS}

The Mann-Whitney U test was used for comparisons of $\mathrm{Hg}, \mathrm{Se}$, and hormone parameters between the different groups. Correlations between $\mathrm{Hg}$ concentrations and hormone parameters were tested with Spearman's rank correlation test. The associations between hormone parameters and $\mathrm{Hg}$ and Se concentrations were tested in a multiple regression analysis allowing for age. Age was dichotomised $(0=\leq 39$ years, $1=\geq 49$ years) in these analyses. The term

Table 1 Concentrations of $\mathrm{Hg}$ and hormone parameters in workers and dentists exposed to elemental Hg vapour and matched referent groups (arithmetic mean (range))

\begin{tabular}{|c|c|c|c|c|}
\hline & $\begin{array}{l}\text { Referents } I \\
(n=10)\end{array}$ & $\begin{array}{l}\text { Hg workers } \\
(n=11)\end{array}$ & $\begin{array}{l}\text { Referents } I I \\
(n=11)\end{array}$ & $\begin{array}{l}\text { Dentists } \\
(n=9)\end{array}$ \\
\hline 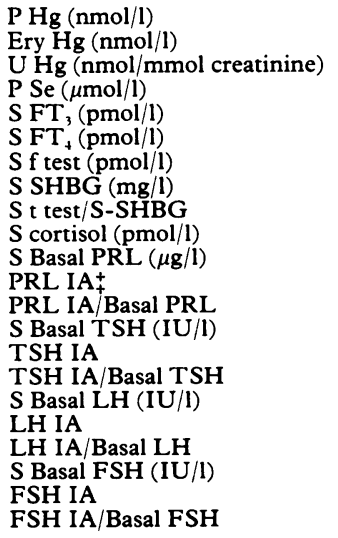 & $\begin{array}{c}5 \cdot 2(1 \cdot 0-14) \\
18(6 \cdot 6-34) \\
0 \cdot 6(0 \cdot 1-1 \cdot 3) \\
1 \cdot 2(0 \cdot 9-1 \cdot 4) \\
6 \cdot 7(5 \cdot 6-8 \cdot 1) \\
15 \cdot 0(12-21) \\
74(35-93) \\
1 \cdot 8(1 \cdot 2-2 \cdot 3) \\
3 \cdot 2(1 \cdot 6-4 \cdot 6) \\
460(190-690) \\
4 \cdot 3(2 \cdot 1-7 \cdot 2) \\
630(400-980) \\
160(95-320) \\
1 \cdot 2(0 \cdot 5-2 \cdot 1) \\
380(220-620) \\
330(240-480) \\
6 \cdot 9(5 \cdot 2-10 \cdot 5) \\
1150(480-3290) \\
170(50-420) \\
3 \cdot 6(1 \cdot 1-10 \cdot 2) \\
210(60-940) \\
50(20-90)\end{array}$ & $\begin{array}{c}93(27-175)^{\star} \\
110(38-310)^{\star} \\
26(14-44)^{\star} \\
1 \cdot 1(0 \cdot 8-1 \cdot 4) \\
6 \cdot 6(4 \cdot 9-8 \cdot 6) \\
15 \cdot 2(11-20) \\
73(42-109) \\
1 \cdot 7(1 \cdot 1-2 \cdot 6) \\
3 \cdot 4(1 \cdot 3-5 \cdot 0) \\
440(210-740) \\
6 \cdot 7(2 \cdot 0-22 \cdot 0) \\
660(210-1450) \\
185(20-480) \\
1 \cdot 3(0 \cdot 9-1 \cdot 7) \\
390(150-710) \\
320(140-590) \\
8 \cdot 3(5-13) \\
1230(390-2870) \\
170(30-500) \\
4 \cdot 2(2 \cdot 3-5 \cdot 6) \\
200(70-490) \\
55(14-190)\end{array}$ & $\begin{array}{c}3 \cdot 9(1 \cdot 5-8 \cdot 7) \\
20(9 \cdot 9-33) \\
0 \cdot 4(0 \cdot 1-1 \cdot 1) \\
1 \cdot 1(0 \cdot 9-1 \cdot 3) \\
6 \cdot 1(5-7 \cdot 1) \\
13 \cdot 6(10-20) \\
61(38-87) \\
2 \cdot 4(1 \cdot 3-3 \cdot 5) \\
2 \cdot 2(1 \cdot 5-3 \cdot 2) \\
393(205-540) \\
3 \cdot 4(1 \cdot 8-6 \cdot 7) \\
540(340-1370) \\
160(100-210) \\
1 \cdot 2(0 \cdot 4-2 \cdot 7) \\
290(90-560) \\
270(160-510) \\
8 \cdot 0(5-11 \cdot 8) \\
920(450-1660) \\
120(60-180) \\
5 \cdot 8(1 \cdot 9-13 \cdot 5) \\
180(60-350) \\
30(20-50)\end{array}$ & $\begin{array}{c}9 \cdot 5(5 \cdot 1-21) \dagger \\
39(20-79) \dagger \\
1 \cdot 3(0 \cdot 5-3 \cdot 9) \dagger \\
1 \cdot 2(1 \cdot 0-1 \cdot 5) \\
5 \cdot 9(5 \cdot 1-6 \cdot 9) \\
14 \cdot 6(10-19) \\
54(38-74) \\
1 \cdot 9(1 \cdot 3-3 \cdot 0) \\
2 \cdot 1(1 \cdot 0-2 \cdot 8) \\
394(310-550) \\
3 \cdot 9(2 \cdot 3-7 \cdot 4) \\
715(280-1710) \\
210(90-740) \\
1 \cdot 2(0 \cdot 4-1 \cdot 6) \\
330(130-490) \\
270(220-320) \\
6 \cdot 9(3 \cdot 4-11 \cdot 7) \\
780(450-2040) \\
110(70-180) \\
6 \cdot 8(1 \cdot 3-27 \cdot 0) \\
260(50-1230) \\
40(10-90)\end{array}$ \\
\hline
\end{tabular}

«Referents I $v \mathrm{Hg}$ workers, $\mathrm{p}<0.0001$.

†Referents II $v$ dentists, $\mathrm{p} \leqslant 0.006$.

$+\mathrm{IA}=$ Incremental area 
significant refers to $p \leq 0 \cdot 05$. All tests were two tailed.

\section{Results}

The $\mathrm{Hg}$ exposed groups had significantly higher concentrations of $\mathrm{P} \mathrm{Hg}$, Ery $\mathrm{Hg}$, and $\mathrm{U} \mathrm{Hg}$ compared with their matched referent groups. The $\mathbf{H g}$ concentrations in the dentists were much lower compared with the industry workers. No significant differences in P Se concentrations were found between the four groups. The exposed groups and their specific referent groups did not differ significantly in any hormone concentration, irrespective of whether basal values, IAs, or relative increments were compared (table 1).

Considering the individual values for all 41 subjects, there were no significant correlations between either $\mathrm{P} \mathrm{Hg}$ or Ery $\mathrm{Hg}$ and any hormone concentration irrespective of basal value, IA, or relative increment. On the other hand, $\mathrm{U} \mathrm{Hg}$ was positively correlated with the basal concentration of $S$ PRL ( $r=0.33, p=0.03$ ) (figure). When age and $P$ Se were allowed for in a multiple regression analysis, association between $\mathrm{U} \mathrm{Hg}$ and the basal concentration of S PRL persisted, although it did not reach the formal significance level $(p=0 \cdot 06)$. Multiple regression analysis did not show any other associations between $\mathrm{U} \mathrm{Hg}, \mathrm{P} \mathrm{Hg}$, or Ery $\mathrm{Hg}$ concentrations and the hormonal parameters. In a multiple regression analysis allowing for age and $\mathrm{U} \mathrm{Hg}$ $\mathrm{P}$ Se was positively associated with basal concentrations of S TSH $(p=0.02)$, and negatively associated with both the relative increment of S FSH $(p=0.01)$ and basal $S$ cortisol concentration $(\mathrm{p}=0.04)$.
Table 2 Age coefficients for hormone concentrations in a multiple regression analysis (41 subjects) allowing for $P$ Se and $U \mathrm{Hg}$ concentrations

\begin{tabular}{|c|c|c|}
\hline Hormones & $\begin{array}{l}\text { Ag } e^{\star} \\
\text { coefficient }\end{array}$ & p Value \\
\hline $\begin{array}{l}\text { S Basal PRL }(\mu \mathrm{g} / \mathrm{l}) \\
\text { PRL IAt } \\
\text { PRL IA/Basal PRL } \\
\text { S Basal TSH (IU/l) } \\
\text { TSH IA } \\
\text { TSH IA/Basal TSH } \\
\text { S Basal LH (IU/l) } \\
\text { LH IA } \\
\text { LH IA/Basal LH } \\
\text { S Basal FSH (IU/l) } \\
\text { FSH IA } \\
\text { FSH IA/Basal FSH } \\
\text { S FT } \text { (pmol/1) } \\
\text { S FT (pmol/l) } \\
\text { S f test (pmol/1) } \\
\text { S t test (ng/ml) } \\
\text { S SHBG (mg/l) } \\
\text { S t test/SHBG } \\
\text { S cortisol (pmol/l) }\end{array}$ & $\begin{array}{l}t \\
= \\
=95 \cdot 3 \\
=69 \cdot 6 \\
= \\
-60 \cdot 0 \\
= \\
-21 \cdot 0 \\
-0.9 \\
=-15 \cdot 4 \\
-0.9 \\
0.4 \\
-1.0 \\
-96.5\end{array}$ & $\begin{array}{l}0.4 \\
>0.5 \\
>0.5 \\
>0.5 \\
0.06 \\
0.04 \\
>0.5 \\
0 \cdot 1 \\
0.05 \\
0 \cdot 1 \\
>0.5 \\
0.04 \\
0.005 \\
0.14 \\
0.006 \\
0.04 \\
0.06 \\
0.003 \\
0.04\end{array}$ \\
\hline
\end{tabular}

*Age was dichotomised $(0=\leqslant 39$ years, $1=\geqslant 49$ years $)$. tCoefficients only mentioned when $p \leqslant 0.06$.

$\ddagger I A=$ Incremental area.

The relative increments of TSH and TSH IAs $\stackrel{\mathscr{Q}}{9}$ were negatively associated with age $(p=0.04$ and $\vec{c}$ $\mathrm{p}=0.06)$, as was $\mathrm{SFT}_{3}(\mathrm{p}=0.005)$ (table $2 \mathrm{p} \bigotimes$ Further, the relative increment of S FSH ( $p=0.04$. and $S \mathrm{f}$ test $(\mathrm{p}=0.006), S \mathrm{t}$ test $(\mathrm{p}=0.04)$ and the ratio of $S t$ test/S SHBG $(p=0.003)$ had significant negative correlations with age. Also, $\mathrm{S}$ cortisol concentration was negatively associated with age $(p=0.04)$.

The most highly exposed worker who, at the time of the stimulation tests had the highest $\mathrm{P} \mathrm{Hg}$ and the

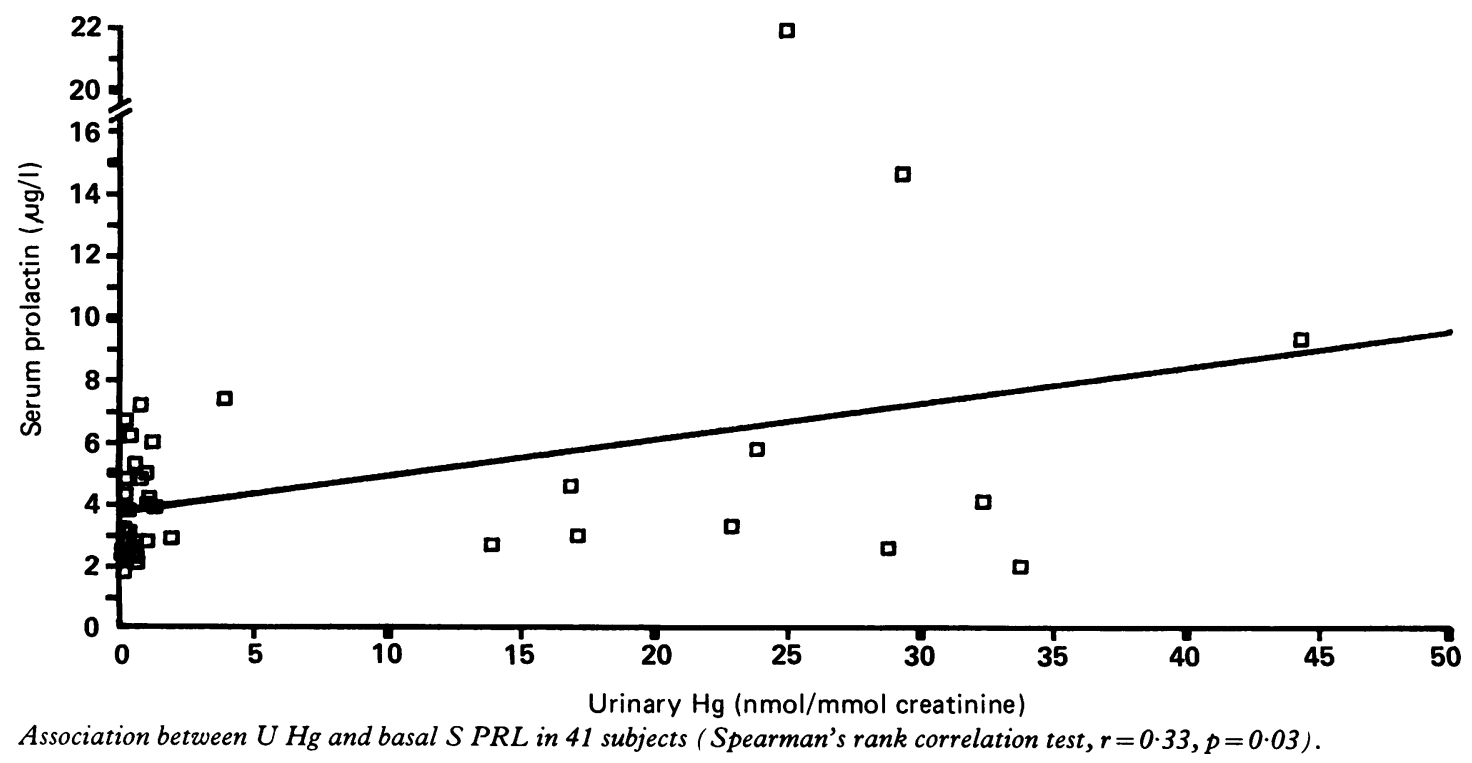

Association between $U \mathrm{Hg}$ and basal S PRL in 41 subjects (Spearman's rank correlation test, $r=0.33, p=0.03$ ). 
second highest $\mathrm{U} \mathrm{Hg}$ concentrations of all subjects, did not exhibit any extreme values within the ranges obtained for the different effect parameters.

\section{Discussion}

Several observations support the reliability of the hormone analysis and the validity of the study groups. Thus in agreement with an earlier study ${ }^{22}$ age was negatively correlated with the relative increment of S TSH. Furthermore, the sex hormone concentrations and their negative association with age also agreed well with earlier studies. ${ }^{23} 24$

Only chloralkali workers with a known relatively high exposure level to elemental $\mathrm{Hg}$ vapour entered the study. The exposure level in the dentists was lower, but the lifetime exposure in the studied group must be considered substantial as they had been working continuously for at least 25 years; compared with another study in which younger dentists were investigated (I Åkesson et al, personal communication) they had higher $\mathbf{P ~} \mathbf{H g}$ and $\mathrm{U} \mathbf{H g}$ concentrations. Furthermore, the P Se concentrations in dentists, chloralkali workers, and in referents were in agreement with the concentrations in other studies of Swedes. ${ }^{13}$

In experimental animals ${ }^{6}$ and in man, ${ }^{15} \mathrm{Hg}$ shows a high affinity for the thyroid. In pigs, the blood thyroxine concentration was reduced after administration of inorganic $\mathrm{Hg}^{6}$ Mercury accumulates in the mouse testis ${ }^{25}$ and exposure to ethyl- $\mathrm{Hg}$ can affect sperm production and reduce libido. ${ }^{26}$ Decreased libido has also been reported after severe exposure to raised concentrations of $\mathrm{Hg}^{27}$ It is not known, however, if an accumulation of $\mathrm{Hg}$ in these organs directly affects the production or secretion of thyroid hormones and testosterone. No differences between thyroid hormones or serum testosterone concentrations could be demonstrated between exposed groups and their referents.

Fifty years ago, Stock was astonished by the high quantities of $\mathrm{Hg}$ in human pituitaries from subjects who had died by accident without any known exposure to $\mathrm{Hg} .{ }^{5}$ Accordingly, Nylander observed that pituitary glands sampled from dentists after death contained excessive amounts of $\mathrm{Hg}$ when compared to the rest of the brain. ${ }^{3}$ In postmortem samples from $\mathrm{Hg}$ mine workers with a long sustained exposure, Kosta et $a^{1}$ showed that the pituitary and the thyroid gland contained the highest concentrations of $\mathrm{Hg}$ in the whole body. Furthermore, Thorlassius-Ussing et al noted that $\mathrm{Hg}$ was present in the thyrotrophs and follicular cells in rat pituitaries, which might be interesting from a functional point of view. We found no effect. The pituitary seems to be a resistant organ as it also has a high capacity to maintain and to regain normal endocrine function after surgery for a pituitary adenoma. ${ }^{28}$
Mercury accumulated intracellularly in the lysosomes and granules of somatrotrophs, thyrotrophs, and corticotrophs. Apart from vacuolation of lysosomes, no structural damage was seen in the cells containing $\mathrm{Hg}^{29}$ Mercury is probably sequestered in lysosomal dense bodies after binding to selenium $^{30}$ and more selenium is retained in subjects with high $\mathrm{Hg}$ concentrations in tissue. ${ }^{131}$

Urinary $\mathrm{Hg}$ correlated positively with basal $\mathrm{S}$ PRL concentrations but Ery $\mathrm{Hg}$ and $\mathrm{P} \mathrm{Hg}$ did not display such correlations, probably due to a poorer association with long term $\mathrm{Hg}$ exposure. Administration of mercury to female hamsters causes alteration in the reproductive system..$^{33}$ This alteration might be due to changes in the pituitary content of FSH and $\mathrm{LH}^{33}$ but increased concentrations of PRL is a possible explanation, as hyperprolactinemia interferes with normal ovulation. ${ }^{34}$ The secretion of PRL is regulated by dopamine, which acts as a PRL inhibitory factor ${ }^{35}{ }^{36}$ Dopamine is released from the median eminence of the hypothalamus, and cell bodies originating from the arcuate nucleus innervate the median eminence. ${ }^{37}$ Mercury has been shown to accumulate in many of the neurons of the arcuate nucleus. ${ }^{33}$ Thus theoretically $\mathrm{Hg}$ could interrupt the dopaminergic inhibition of prolactin secretion at the hypothalamic level. The significant correlation between basal S PRL and $\mathrm{U} \mathrm{Hg}$ concentrations is, however, based mainly on a small group of chloralkali workers some of which had high $\mathrm{U} \mathrm{Hg}$ concentrations and increased concentrations of $S$ PRL. Thus a further study comprising a larger group of workers with high exposure to $\mathrm{Hg}$ is needed to obtain a firmer conclusion.

Plasma Se concentration was positively associated with basal S TSH concentration and negatively associated with the relative increment of S FSH and with basal $S$ cortisol concentration. It is interesting that Se accumulates intracellularly in the secretory granules of the thyrotrophs, gonadotrophs, corticotrophs, and somatotrophs in rats after high exposure. ${ }^{38}$ Functionally, accumulation of $\mathrm{Se}$ in somatotrophs might be important as rats treated with very high doses of Se had markedly reduced growth and growth hormone secretion. ${ }^{9}$

The study was supported by grants from the Swedish Work Environment Fund and the National Swedish Environment Protection Board. Technical help was given by Ms Anna Akantis, Ms Birgitta Björk, Mr Anders Ekholm, Ms Katarina Lindén, and Ms Brita Sundén.

\footnotetext{
1 Kosta L, Byrne AR, Zelenko V. Correlation between selenium and mercury in man following exposure to inorganic mercury. Nature 1975;254:238-9.

2 Hargreaves RJ, Evans JG, Janota I, Magos L, Cavanagh JB. Persistent mercury in nerve cells 16 years after metallic mercury poisoning. Neuropathol Appl Neurobiol (in press).

3 Nylander M. Mercury in pituitary glands of dentists. Lancet $1986 ; \mathrm{i}: 442$.
} 
4 Thorlacius-Ussing O, Møller-Madsen B, Danscher G. Intracellular accumulation of mercury in the anterior pituitary of rats exposed to mercuric chloride. Exp Mol Pathol 1985; 42:278-86.

5 Stock A. Der Quecksilbergehalt des menschlichen organismus. XXX. Mitteilung über Wirkung und Verbreitung des Quecksilbers. Biochemische Zeitschrift 1940;304:73-80.

6 Kawada J, Nishida M, Yoshimura Y, Mitani K. Effects of organic and inorganic mercurials on thyroidal functions. Journal of Pharmacobio-Dynamics 1980;3:149-59.

7 Sümegi S, Putnoky J. Experimentelle Schwermetallvergiftungen, Schilddrüsenfunktion und Porphyrie. Archiv für Gewerbepathologie und Gewerbehygiene 1939;9:566-91.

8 Becket GJ, Beddows SE, Morrice PC, Nicol F, Arthur JR. Inhibition of hepatic deiodination of thyroxine is caused by selenium deficiency in rats. Biochem $J$ 1987;248:443-7.

9 Thorlacius-Ussing O, Flyvbjerg A, Esmann J. Evidence that selenium induces growth retardation through reduced growth hormone and somatomedin C production. Endocrinology 1987;120:659-63.

10 Högberg J, Alexander J. Selenium. In: Friberg L, Nordberg GF, Vouk VB. Handbook on the toxicology of metals. Amsterdam: Elsevier, 1986; Vol II:482-520.

11 Suzuki $T$, Himeno $S$, Hongo $T$, Watanabe C, Satoh $H$ Mercury-selenium interaction in workers exposed to elemental mercury vapor. J Appl Toxicol 1986;6:149-53.

12 Alexander J, Thomassen Y, Aaseth J. Increased urinary excretion of selenium among workers exposed to elemental mercury vapor. J Appl Toxicol 1983;3:143-5.

13 Svensson BG, Björnham Å, Schütz A, Lettevall U, Nilsson A, Skerfving $S$. Acidic deposition and human exposure to toxic metals. Sci Total Environ 1987;67:101-15.

14 Mortimer CH, Besser GM, McNeilly AS, Tunbridge WMG Gomez-Pan A, Hall R. Interaction between secretion of the gonadotrophins, prolactin, growth hormone, thyreotrophin and corticosteroids in man: The effect of LH/FSH-RH, TRH and hypoglycaemia alone and in combination. Clin Endocrinol (Oxf) 1973;2:317-26.

15 Badawy ZA, Cittadino R, Marshall L. Testosterone estradiol binding globulin ratio in evaluating hirsute women. Int $J$ Fertil 1982;27:166-70.

16 Fernlund P, Gershagen S, Larsson I, Rannevik G. Radioimmunoassay of human sex hormone binding globulin: improved radioiodination procedure. Scand J Clin Lab Invest 1985;45:461-9.

17 Einarsson Ö, Lindstedt G, Bergströ T. A computerized automatic apparatus for determination of mercury in biological samples. J Autom Chem 1984;6:74-79.

18 Barregård L, Hultberg B, Schütz A, Sällsten G. Enzymuria in workers exposed to inorganic mercury. Int Arch Occup Environ Health 1988;61:65-9.

19 LaLonde L, Jean Y, Roberts KD, Chatdelaine KD, Bleau G. Fluorometry of selenium in serum or urine. Clin Chem 1982;28:172-74

20 Ohlsson K, Schütz A, Attewell R, Skerfving S. Selenium status in females with occupational cervio-brachial complaints. Int Arch Occup Environ Health 1988;61:167-9.

21 Lustgarten JA, Wenk RE. Simple, rapid kinetic method for serum creatinine measurement. Clin Chem 1972;18:1419-22.

22 Erfurth EM, Nordén NE, Hedner P, Nilsson A, Ek L. Normal reference interval for thyrotropin response to thyroliberin: Dependence on age, sex, free thyroxine index, and basal concentrations of thyrotropin. Clin Chem 1984;30:196-9.

23 Snyder PJ, Reitano J, Utiger R. Serum LH and FSH responses to synthetic gonadotrophin-releasing hormone in normal men. $J$ Clin Endocrinol Metab 1975;41:938-45.

24 Harman SM. Clinical aspects of aging of the male reproductive system. In: Schneider EL, ed. The aging reproductive System. New York: Raven Press, 1978;4:29.

25 Berlin M, Ullberg S. Accumulation and retention of mercury in the mouse. I. An autoradiographic study after a single $\backsim$ intravenous injection of mercuric chloride. Arch Environ $\vec{\circ}$ Health 1963;6:589-601.

26 Popescu HI. Poisoning with alkylmercury compounds. $\mathrm{Br} \mathrm{Med} \mathrm{J}$ 1978;1:1347.

27 McFarland RB, Reigel $H$. Chronic mercury poisoning from a single brief exposure. J Occup Med 1978;20:532-4.

28 McLanahan CS, Christy JH, Tindall GT. Anterior pituitary function before and after surgery before and after trans- ? phenoidal microsurgical resection of pituitary tumours. A Neurosurgery 1979;3:142-5.

29 Möller-Madsen B, Thorlacius-Ussing O. Accumulation of mercury in the anterior pituitary of rats following oral or intraperitoneal administration of methyl mercury. Virchows Arch /B 7 1986;51:303-11.

30 Cavanagh JB. Long term persistence of mercury in the brain. $B r \stackrel{ }{\supset}$ $J$ Ind Med 1988;45:649-51.

31 Rossi LC, Clemente GF, Santaroni G. Mercury and selenium $\odot$ distribution in a defined area and its population. Arch Environ $(D$ Health 1976;31:160-5.

32 Lamperti AA, Printz RH. Localization, accumulation, and toxic effects of mercuric chloride on the reproductive axis of the female hamster. Biol Reprod 1974;11:180-6.

33 Lamperti A, Niewenhuis $R$. The effects of mercury on the structure and function of the hypothalamo-pituitary axis in the hamster. Cell Tissue Res 1976;170:315-24.

34 Thorner MO, Besser GM, Jones A, Dacie J, Jones A 눙 Bromocriptin treatment of female infertility: report of pregnancies. Br Med J 1975;4:694-7.

35 Fuxe K, Hökfelt T. Catecholamines in the hypothalamus and the pituitary gland. In: Ganong WF, Martini L, eds. Frontiers in Neuroendocrinology. New York: Oxford University Press, 1969:47-96.

36 Hökfelt T, Fuxe K. Effects of prolactin and ergot alkaloids on the tubero-infundibular dopamine(DA)neurons. Neuroendocrino$\log y$ 1972;9:100-22.

37 Fuxe K, Hökfelt T. Further evidence for the existence of tuberoinfundibular dopamine neurons. Acta Physiol Scand 1966; 66:245-6.

38 Thorlacius-Ussing O, Danscher G. Selenium in the anterior pituitary of rats exposed to sodium selenite: Light and electron microscopic localization. Toxicol Appl Pharmacol 1985;81: 67-74.

Accepted 19 March 1990 